\title{
Neurotropic viruses and Alzheimer's disease: a search for varicella zoster virus DNA by the polymerase chain reaction
}

\author{
Woan-Ru Lin, Inma Casas, Gordon K Wilcock, Ruth F Itzhaki
}

\begin{abstract}
Background-In studies on the possible role of viruses in the aetiopathogenesis of Alzheimer's disease, herpes simplex virus type 1 (HSV1) DNA was detected by the polymerase chain reaction (PCR) in a high proportion of normal elderly people and of patients with Alzheimer's disease. The combination of HSV1 and a host factor, the type 4 allele of the gene for apolipoprotein $E$, is a strong risk factor for the disease.

Methods-Brain specimens were examined for another herpes virus, varicella zoster (VZV), which, like HSV1, is neurotropic, has a predilection for residing latently in the peripheral nervous system, and can reactivate.

Results-Using primers for sequences in the VZV origin of replication gene or thymidine kinase gene, VZV DNA was not found in any of 24 samples (18 HSV1 positive), from 17 patients with Alzheimer's disease, nor in 20 samples (12 HSV1 positive from 12 aged normal people. Hybridisation of the PCR products with a radiolabelled oligonucleotide probe capable of detecting less than 10 copies of the target sequence, confirmed the absence of VZV DNA.

Conclusion-The presence of one neurotropic virus-HSV1-and the absence of another-VZV-in aged human brains is consistent with a role for HSV1 in the aetiology of Alzheimer's disease.
\end{abstract}

$(\mathcal{F}$ Neurol Neurosurg Psychiatry 1997;62:586-589)

Keywords: Alzheimer's disease; aetiology; varicella zoster virus; polymerase chain reaction; herpes simplex type 1 virus

Two of the herpes viruses-herpes simplex virus type 1 (HSV1) and varicella zoster virus (VZV)-can reside latently in the peripheral nervous system (PNS). Most humans are infected with these viruses at a relatively early age; most remain asymptomatic throughout their lives, but in some people reactivation of HSV1 occurs periodically under conditions such as stress or immunosuppression, usually causing cold sores. In other people, reactivation can be asymptomatic. VZV usually reactivates only once, causes shingles, and lacks asymptomatic shedding. ${ }^{1}$ In rare cases either virus can cause an acute infection of the CNS leading to encephalitis, although it is uncertain whether this results from exogenous or endogenous infection-that is, from new infection or from migration to the CNS of reactivated virus from the PNS.

Other common viruses-for example, measles virus - can, again in rare cases, cause serious neurological disease, even after persisting for many years in the host without any apparent ill effects. HSV1 has been proposed as a possible aetiological agent for Alzheimer's disease partly because of its propensity for residing latently in nervous tissue and partly because in acute herpes encephalitis (HSE), it affects the regions of the brain which are those most affected in Alzheimer's disease. However, until recently, it was uncertain whether or not HSV1 (or VZV) could reside latently in the CNS. Conflicting results (see review ${ }^{2}$ ) were obtained from studies on HSV1 using dot or Southern blotting or in situ hybridisation: some authors claimed to detect the viral DNA in brains from normal subjects and from patients with Alzheimer's disease, whereas others failed to do so. The sensitivity of the methods used, though, was such that HSV1 DNA would have been detectable only if present at a level of at least one copy per cell genome.

With the advent of the polymerase chain reaction (PCR), detection of viruses in general in the CNS became a much more feasible proposition. We have used PCR to investigate brain specimens from normal people and from patients with Alzheimer's disease for the presence of HSV1 DNA. We have detected the viral DNA in a high proportion of elderly normal subjects and of patients with Alzheimer's disease; the infection seems to be latent and is present usually in the temporal and frontal cortex and hippocampus - the regions most affected in Alzheimer's disease. ${ }^{3}$ Viral DNA is absent in the occipital cortex-a region much less affected in the disease. We have not found the viral DNA in brain specimens from younger people. ${ }^{4}$ We postulated that in those older people who harbour HSV1 in their CNS, limited reactivation occurs periodically in the CNS during episodes of stress or immunosuppression, causing cumulative damage, and that these episodes are more harmful in those destined to develop Alzheimer's disease because of differences in host specific or virus specific factors. ${ }^{5}$ (It should be noted that cases of mild HSE have been described from which patients recover completely, apart from a slight loss of memory or other minor neurological defects. ${ }^{6}$ ) We then investigated one host factor-the apolipoprotein E (apoE) genotype; 
possession of an apoE4 allele is a known risk factor for Alzheimer's disease ${ }^{7}$ but is neither necessary nor sufficient for development of the disease. We found that there is a very strong correlation in patients with Alzheimer's disease between the presence of HSV1 in brain and possession of an apoE4 allele-that is, the apoE4 allele frequency is very much higher in those patients with Alzheimer's disease who are HSV1-positive in brain than in those who are HSV1-negative, and than in HSV1-positive and negative normal subjects. ${ }^{8-10}$ These results, combined with results of a study which showed that people who have cold sores had a far higher apoE4 allele frequency than those who do not, ${ }^{8-10}$ indicated that the combination of possession of an apoE4 allele and HSV1 presence in the brain is very damaging in the nervous system, and that the two factors, when combined, confer a strong risk of developing Alzheimer's disease.

As to whether the other neurotropic virus, $\mathrm{VZV}$, is present in the CNS of normal people or patients with Alzheimer's disease, only two studies (using PCR) have previously sought evidence; in one, VZV DNA was not detected in the one brain examined, ${ }^{11}$ from a young normal subject, and in the other, none was detected in brains from eight schizophrenic patients nor from eight normal subjects, ${ }^{12}$ all but one of whom were young. In view of our findings with HSV1, including the age dependence, we decided to search for VZV in postmortem human brain specimens from aged normal subjects as well as from patients with Alzheimer's disease, using PCR.

\section{Subjects and methods}

Patients with Alzheimer's disease had a history of dementia and the neuropathological features of Alzheimer's disease; they comprised five men and 12 women, aged 57-96 (mean
79) years. Normal subjects comprised eight men and four women, aged 58-90 (mean 75) years, all with no signs or history of a CNS disorder. Specimens were obtained postmortem from temporal or frontal cortex or hippocampus and in seven of the patients with Alzheimer's disease and seven of the normal patients, were from two of these regions (table).

DNA was prepared from brain, and "positive control" DNA was prepared from cell cultures of human embryonic lung fibroblast (HELF) infected with VZV, as described previously. Great care was taken to prevent cross contamination $^{3}$ by stringent cleaning of homogenisers with decon, $10 \% \mathrm{HCl}$, and ethanol, and by the use of separate laboratories for the preparation of the DNA, setting up PCR, amplification, and electrophoresis. We had previously examined the brain DNA by PCR for the presence or absence of the HSV1 thymidine kinase (TK) gene sequence. Purified VZV DNA was donated by Dr A Davison, University of Glasgow, for use in experiments to determine the sensitivity of detection of the target sequences. The PCR and agarose gel electrophoresis were carried out as described previously ${ }^{2}$ but using a 20 base primer pair specific for VZV DNA amplifying a $325 \mathrm{bp}$ sequence within the origin of replication (OR) gene. The amplification procedure was modified accordingly. To confirm our results, a second PCR for a discrete 296 bp region of the VZV TK gene was performed on some samples (TPS Powell et al, unpublished data). The specificity of the primers for the VZV genome was confirmed by the lack of amplification on testing the OR primers with DNA from BSC-1 cells (African green monkey epithelial cells) and the TK primers with DNA from uninfected HELF cells. For the OR primer, DNA was amplified in a $50 \mu \mathrm{l}$ reaction mixture containing $1 \mu \mathrm{g}$ DNA, 10

Non-detection of VZV DNA in Alzheimer's disease and aged normal brains

\begin{tabular}{|c|c|c|c|c|c|c|c|c|c|c|c|}
\hline \multicolumn{6}{|c|}{ Alzheimer's disease } & \multicolumn{6}{|c|}{ Age matched normal aged brains } \\
\hline $\begin{array}{l}\text { Patient } \\
\text { No }\end{array}$ & Sex & Age & Brain region & $H S V 1$ & $V Z V$ & $\begin{array}{l}\text { Patient } \\
\text { No }\end{array}$ & Sex & Age & Brain region & $H S V 1$ & $V Z V$ \\
\hline 1 & $\mathrm{~F}$ & 78 & Hippocampus & - & OR & 18 & $\mathbf{M}$ & 78 & $\begin{array}{l}\text { Midfrontal (B6) } \\
\text { Sup temporal (B22) } \\
\text { Occipital (B17) }\end{array}$ & $\begin{array}{l}+ \\
+ \\
+\end{array}$ & $\begin{array}{l}\text { OR, TK } \\
\text { OR } \\
\text { OR }\end{array}$ \\
\hline $\begin{array}{l}2 \\
3\end{array}$ & $\begin{array}{l}\mathrm{M} \\
\mathrm{F}\end{array}$ & $\begin{array}{l}73 \\
73\end{array}$ & $\begin{array}{l}\text { Sup temporal (B22) } \\
\text { Sup temporal (B22) } \\
\text { Hippocampus }\end{array}$ & $\begin{array}{l}+ \\
+ \\
+\end{array}$ & $\begin{array}{l}\text { OR, TK } \\
\text { OR, TK } \\
\text { OR }\end{array}$ & $\begin{array}{l}19 \\
20\end{array}$ & $\begin{array}{l}M \\
M\end{array}$ & $\begin{array}{l}73 \\
81\end{array}$ & $\begin{array}{l}\text { Midfrontal (B6) } \\
\text { Midfrontal (B6) }\end{array}$ & $\begin{array}{l}+ \\
+\end{array}$ & $\begin{array}{l}\text { OR } \\
\text { OR, TK }\end{array}$ \\
\hline $\begin{array}{l}4 \\
5 \\
6 \\
7\end{array}$ & $\begin{array}{l}\mathrm{F} \\
\mathrm{M} \\
\mathrm{F} \\
\mathrm{F}\end{array}$ & $\begin{array}{l}77 \\
76 \\
86 \\
96\end{array}$ & $\begin{array}{l}\text { Midfrontal (B6) } \\
\text { Hippocampus } \\
\text { Midfrontal (B6) } \\
\text { Midfrontal (B6) }\end{array}$ & $\begin{array}{l}+ \\
+ \\
+ \\
+\end{array}$ & $\begin{array}{l}\text { OR, TK } \\
\text { OR } \\
\text { OR } \\
\text { OR }\end{array}$ & $\begin{array}{l}21 \\
22 \\
23 \\
24\end{array}$ & $\begin{array}{l}M \\
M \\
F \\
F\end{array}$ & $\begin{array}{l}64 \\
58 \\
73 \\
85\end{array}$ & $\begin{array}{l}\text { Sup temporal (B22) } \\
\text { Sup temporal (B22) } \\
\text { Sup temporal (B22) } \\
\text { Frontal end (B10) } \\
\text { Midtemporal (B20/21) }\end{array}$ & $\begin{array}{l}- \\
-\end{array}$ & $\begin{array}{l}\text { OR, TK } \\
\text { OR } \\
\text { OR } \\
\text { OR } \\
\text { OR }\end{array}$ \\
\hline 8 & $\mathrm{~F}$ & 91 & Hippocampus & - & OR & 25 & $\mathbf{M}$ & 62 & $\begin{array}{l}\text { Frontal end (B10) } \\
\text { Midtemporal (B20/21) }\end{array}$ & - & $\begin{array}{l}\text { OR } \\
\text { OR }\end{array}$ \\
\hline 9 & $\mathbf{M}$ & 73 & $\begin{array}{l}\text { Frontal end (B10) } \\
\text { Midtemporal (B20/21) }\end{array}$ & $\begin{array}{l}- \\
-\end{array}$ & $\begin{array}{l}\text { OR } \\
\text { OR }\end{array}$ & 26 & $\mathbf{F}$ & 81 & $\begin{array}{l}\text { Frontal end (B10) } \\
\text { Midtemporal (B20/21) }\end{array}$ & $\begin{array}{l}+ \\
-\end{array}$ & $\begin{array}{l}\text { OR } \\
\text { OR }\end{array}$ \\
\hline 10 & $\mathrm{~F}$ & 82 & $\begin{array}{l}\text { Frontal end (B10) } \\
\text { Midtemporal (B20/21) }\end{array}$ & $\begin{array}{l}+ \\
-\end{array}$ & $\begin{array}{l}\text { OR } \\
\text { OR }\end{array}$ & 27 & $\mathbf{F}$ & 73 & $\begin{array}{l}\text { Frontal end (B10) } \\
\text { Midtemporal (B20/21) }\end{array}$ & $\begin{array}{l}+ \\
+\end{array}$ & $\begin{array}{l}\text { OR } \\
\text { OR }\end{array}$ \\
\hline 11 & $\mathbf{M}$ & 80 & $\begin{array}{l}\text { Frontal end (B10) } \\
\text { Midtemporal (B20/21) }\end{array}$ & $\begin{array}{l}+ \\
+\end{array}$ & $\begin{array}{l}\text { OR } \\
\text { OR }\end{array}$ & 28 & $\mathbf{M}$ & 84 & $\begin{array}{l}\text { Frontal end (B10) } \\
\text { Midtemporal (B20/21) }\end{array}$ & $\begin{array}{l}+ \\
+\end{array}$ & $\begin{array}{l}\text { OR } \\
\text { OR }\end{array}$ \\
\hline 12 & $\mathrm{~F}$ & 80 & $\begin{array}{l}\text { Frontal end (B10) } \\
\text { Midtemporal (B20/21) }\end{array}$ & $\begin{array}{l}+ \\
-\end{array}$ & $\begin{array}{l}\text { OR } \\
\text { OR }\end{array}$ & 29 & $\mathbf{M}$ & 90 & $\begin{array}{l}\text { Frontal end (B10) } \\
\text { Midtemporal (B20/21) }\end{array}$ & \pm & $\begin{array}{l}\text { OR } \\
\text { OR }\end{array}$ \\
\hline 13 & $\mathrm{~F}$ & 90 & $\begin{array}{l}\text { Frontal end (B10) } \\
\text { Midtemporal (B20/21) }\end{array}$ & $\begin{array}{l}+ \\
+\end{array}$ & $\begin{array}{l}\text { OR } \\
\text { OR }\end{array}$ & & & & & & \\
\hline 14 & F & 75 & $\begin{array}{l}\text { Frontal end (B10) } \\
\text { Midtemporal (B20/21) }\end{array}$ & $\begin{array}{l}+ \\
+\end{array}$ & $\begin{array}{l}\text { OR } \\
\text { OR }\end{array}$ & & & & & & \\
\hline $\begin{array}{l}15 \\
16 \\
17\end{array}$ & $\begin{array}{l}\mathrm{F} \\
\mathbf{M} \\
\mathrm{F}\end{array}$ & $\begin{array}{l}57 \\
75 \\
81\end{array}$ & $\begin{array}{l}\text { Midtemporal (B20/21) } \\
\text { Frontal end (B10) } \\
\text { Frontal end (B10) }\end{array}$ & $\begin{array}{l}+ \\
+ \\
+\end{array}$ & $\begin{array}{l}\text { OR } \\
\text { OR } \\
\text { OR }\end{array}$ & & & & & & \\
\hline
\end{tabular}


$\begin{array}{llllllllll}M & 1 & 2 & 3 & 4 & 5 & 6 & 7 & 8 & 9\end{array}$

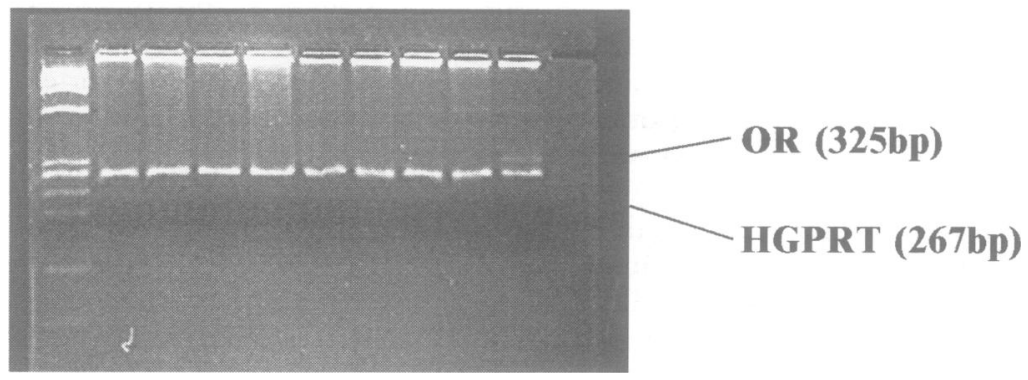

Figure $1 \quad P C R$ assay of DNA from aged normal and Alzheimer's disease brain using VZV OR primer pair (and human HGPRT). Lane M: marker $\Phi X 174$ DNA, Hae-III digested; lanes 1-6, Alzheimer's disease DNA; lanes 7-8, aged normal DNA; lane 9, $V Z V$ infected cell DNA. OR primer concentration was $1 \mu M$ and HGPRT primer concentration was $0.05 \mu M$ in most assays.

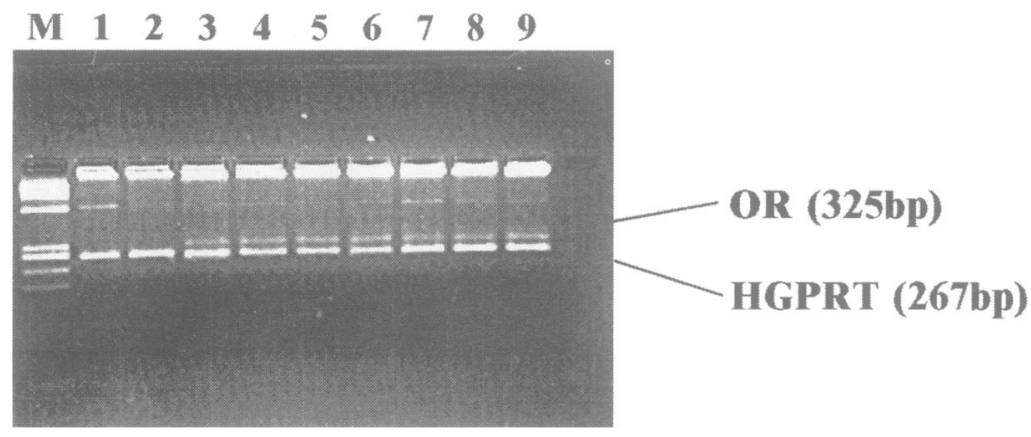

Figure 2 Check for interference in $P C R$ assay, using VZV OR primer pair. Lane $M$ : marker $\Phi X 174$ DNA, Hae-III digested; lanes 1, 4, 7, Alzheimer's disease DNA; lanes 2, 5, 8, aged normal DNA; lanes 3, 6, 9, VZV infected cell DNA; lanes 4, 7, Alzheimer's disease DNA mixed with VZV infected cell DNA; lanes 5, 8, aged normal DNA mixed with VZV infected cell DNA. OR primer concentration was $1 \mu M$ in all assays; HGPRT primer concentration was 0.1 $\mu \mathrm{M}$ in lanes $1-3$ and 7-9 and 0.05 $\mu \mathrm{M}$ in lanes 4-6.

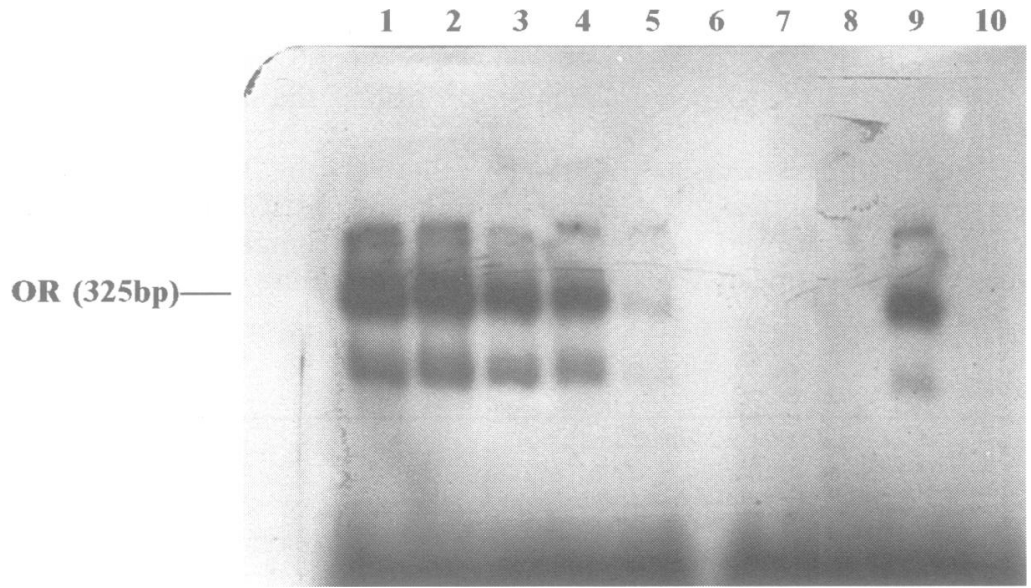

Figure 3 Autoradiograph of pure VZV DNA and brain DNA after hybridisation to a radiolabelled probe of sequence internal to the amplified $O R$ gene sequence. Number of VZV molecules per assay in lanes $1-5,10^{4}, 10^{3}, 10^{2}, 10,1$; lane 6 , no sample; lanes 7-10, aged normal $D N A$, Alzheimer's disease DNA, VZV infected cell DNA, and reagent blank. $72^{\circ} \mathrm{C}$ (extension) step was continued for five minutes. We routinely checked for the absence of interference in our PCR assays by using primers for a human DNA sequence-within the HGPRT gene-in the same tube as primers for VZV DNA sequences; results were accepted only if the sample was positive for HGPRT. Possible cross contamination was routinely monitored using a buffer "blank" which had been subjected to the same procedures as the brain samples.

Solution hybridisation of PCR products with an end labelled oligonucleotide probe internal to the OR amplified sequence, ${ }^{13}$ followed by autoradiography, was used for determining the specificity of amplification; also, using amplified serial dilutions of purified VZV DNA, the sensitivity of detection of amplified VZV OR DNA was estimated.

\section{Results}

Figure 1 shows the results for eight samplestwo normal aged subjects, six with Alzheimer's disease - of brain DNA using primers for the VZV OR gene sequence, and for the human HGPRT gene sequence. There was no evidence of VZV DNA in any of the samples and this was true of a further 18 normal and 18 Alzheimer's disease samples tested (table). The presence of amplified OR sequence in the positive controls, and of the human HGPRT sequence in all samples, showed that no interference was occurring in the PCR. As a further check, two brain DNA samples-one Alzheimer's disease, one normal-which showed no amplified VZV product were each mixed with DNA from the VZV infected cells - that is, with known positives, and the mixtures were tested by PCR. Figure 2 shows that amplification of the positives was obtained, indicating that the negative brain samples contained no interfering contaminant. Three Alzheimer's disease and three aged normal brain DNA samples were tested further using primers for the VZV TK sequence and showed similarly negative results. Of the 24 Alzheimer's disease DNA specimens, 18 were HSV1 TK positive. Of the 20 aged normal specimens, 12 were HSV1 TK-positive and two were untested.

To find if the sensitivity of the PCR was as great for the VZV OR DNA sequences as for the HSV1 TK DNA sequence, we prepared serial dilutions of purified VZV DNA, amplified the OR sequence in each, and hybridised the products together with three amplified brain DNA samples. Figure 3 displays the autoradiograph and shows that well under 10 VZV sequences per tube are detectable, and that no VZV DNA signal is visible for any of the brain samples (two Alzheimer's disease, one normal). The usual ethidium bromide staining was sensitive to less than $10 \mathrm{VZV}$ sequences per tube. These values are very similar to those previously obtained for the minimum level of detectability of the HSV1 TK sequence (GA Jamieson and RF Itzhaki, unpublished data) so we conclude that our negative findings for VZV DNA in our aged 
normal and Alzheimer's disease brain samples, most of which contained HSV1 DNA, are not due to an inadequate level of detectability of VZV DNA.

\section{Discussion}

It seems that although latent HSV1 resides in certain regions of the CNS of many aged normal subjects and patients with Alzheimer's disease, VZV is absent in those brain regions. There are at least two possible explanations for this difference, depending on whether the CNS infection results from exogenous or endogenous virus (at least in the case of HSV1 encephalitis, infection may be exogenous or due to endogenous virus reactivated from latency in the PNS. ${ }^{1415}$ Firstly, VZV recurrence usually occurs only once, and only several months after immunosuppression, whereas that of HSV1 is very frequent, and occurs within one to four weeks of immunosuppression. ${ }^{1}$ Thus if infection of the CNS is endogenous - that is, due to virus reactivated from the PNS - the probability of such an occurrence would be far greater with HSV1 than with VZV. Secondly, if viral infection of the CNS is of exogenous origin, one likely route is via the olfactory bulb, ${ }^{16}$ and as $\mathrm{HSV}$ has been found to be latent in $15 \%$ of olfactory bulbs whereas VZV is latent in only $1 \%,{ }^{17}$ the probability of viral entry to the CNS by this route, as well as of recurrence, would be far greater for HSV1 than for VZV. We have suggested that in Alzheimer's disease there may be more damaging episodes of reactivation of HSV1 in the CNS than in aged normal subjects. ${ }^{5}$ It may be relevant that some patients with Alzheimer's disease have an impaired sense of smell and difficulties in olfactory discrimination. ${ }^{18}$ This could well reflect more extensive reactivation of HSV1 in the olfactory pathway in Alzheimer's disease than in the normal elderly subjects, consistent with our hypothesis.

A further possible explanation relates to differences in gene expression during latency. In the case of HSV1 only the latency associated transcripts have been detected, and these are not polyadenylated. By contrast, several VZV immediate early and early genes seem to be expressed in latency and these are polyadenylated; it has therefore been suggested that cells latently infected with VZV might be "recognised" by the host immune system, ${ }^{19}$ resulting presumably in a restricted extent of reactivation and hence reducing the likelihood of entry into the CNS.

Thus the presence of HSV1 and the absence of $\mathrm{VZV}$, another neurotropic herpes virus with a similar propensity for latency, in the CNS of many aged subjects and patients with Alzheimer's disease - and the association of HSV1 in the patients with Alzheimer's disease with possession of an apoE4 allele-suggest that HSV1, but not VZV, plays a specific and major part in the aetiopathogenesis of Alzheimer's disease.

We are grateful to the Sir Halley Stewart Trust for a grant, and to Mettler-Toledo for a donation in support of this work. We to Mettler-Toledo for a donation in support of this work. Dr P also thank Professor N Maitland for the VZV OR primers, Dr $P$ assistance. This work benefited from the use of the Seqnet assistance. This work benefited from the use

1 Meier JL, Straus SE. Comparative biology of latent varicella-zoster virus and herpes simplex virus infections. $\mathscr{f}$ Infect Dis 1992;166:S13-23

2 Itzhaki RF. Possible factors in Alzheimer's disease. Mol Neurobiol 1994;9:1-13.

3 Jamieson GA, Maitland NJ, Wilcock GK, Craske J, Itzhak RF. Latent herpes simplex virus type 1 in normal and Alzheimer's disease brains. F Med Virol 1991;33:224-7.

4 Jamieson GA, Maitland NJ, Wilcock GK, Yates CM, Itzhaki RF. Herpes simplex virus type $1 \mathrm{DNA}$ is present in specific regions of brain from aged people with and without senile dementia of the Alzheimer type. $\mathcal{F}$ Pathol 1992 ; 167:365-8.

5 Itzhaki RF, Maitland NJ, Wilcock GK, Yates CM, Jamieson GA. Detection by polymerase chain reaction of herpes simplex virus type 1 (HSV1) DNA in brain of herpes simplex virus type aged normals and Alzheimer's disease patients. In: Corain B, Iqbal K, Nicolini M, Winblad B, Wisniewsk $\mathrm{H}$, Zatta P, eds. Alzheimer's disease: advances in
and basic research. Chichester: John Wiley, 1993.

6 Klapper PE, Cleator GM, Longson M. Mild forms of herpe encephalitis. I Neurol Neurosurg Psychiatry 1984;47 1247-50.

7 Corder EH, Saunders AM, Strittmatter WJ, Schemechel DE, Gaskell PC, Small GW, et al. Gene dose of apoliprotein E type 4 allele and the risk of Alzheimer's disease in late onset families. Science 1993;261:921-3.

8 Lin W-R, Shang D, Wilcock GK, Itzhaki RF. Alzheimer's disease, herpes simplex virus type 1 , cold sores and disease, herpes simplex virus type 1, cold sores
apolipoprotein E4. Biochem Soc Trans 1995;23:594S.

9 Lin W-R, Shang D, Itzhaki RF. Neurotropic viruses and Alzheimer's disease: interaction of herpes simplex type 1 virus and apolipoprotein $\mathrm{E}$ in the aetiology of the disease. Mol Chem Neuropathol 1996;28:135-41.

10 Itzhaki RF, Lin W-R, Shang D, Wilcock GK, Faragher B, Jamieson GA. Herpes simplex virus type 1 in brain is a risk factor for Alzheimer's disease. Lancet 1997;349. $241-4$.

11 Mahalingam R, Wellish M, Wolf W, Dueland AN, Cohrs $R$, Vafai A, Gilden D. Latent varicella-zoster viral DNA in human trigeminal and thoracic ganglia. $N$ Engl $\mathcal{f}$ Med 1990;323:627-31.

12 Alexander RC, Cabirac G, Lowenkopf T, Casanova M, Kleinman J, Wyatt RJ, Kirsch DG. Search for evidence of herpes simplex virus type 1, or varicella-zoster virus infection in postmortem brain tissue from schizophrenic infection in postmortem brain tissue from sch

13 Kellogg DE, Sninsky J, Kwok S. Quantitation of HIV-1 proviral DNA relative to cellular DNA by the polymerase proviral DNA relative to cellular DNA by the poly

14 Nahmias AJ, Whitley RJ, Visintim AN, Takei Y, Alford CA. Herpes simplex virus encephalitis: laboratory evaluations and their diagnostic significance. $\mathcal{F}$ Infect Dis 1982 145:829-37.

15 Whitley R, Lakeman AD, Nahmias A, Roizman BL. DNA restriction enzyme analysis of herpes simplex virus isolates obtained from patients with encephalitis. $N$ Engl $f$ Med 1982;307:1060-2.

16 Pearson RCA, Powell TPS. The neuroanatomy of Alzheimer's disease Rev Neurosci 1989;2:101-22.

17 Liedtke W, Opalka B, Zimmermann CW, Lignitz E. Age distribution of latent herpes simplex virus 1 and varicelladistribution of latent herpes simplex virus 1 and varicellazoster virus gen

18 Doty RL, Reyes PF, Gregor T. Presence of both odor identification and detection deficits in Alzheimer's disease. Brain Res Bull 1987;18:597-600.

19 Oxman MN. Immunization to reduce the frequency and severity of herpes zoster and its complications. Neurology 1995;45(suppl 8):S41-6 